\title{
膨圧性泥質岩地山におけるトンネルの 多重支保工の効果
}

\author{
剣持三平 1 -竹津英二 $2 \cdot$ 青木智幸 $3 \cdot$ 森田隆三郎 4 ・白旗秀紀 5 \\ 1フェロー会員（株）フジタ（†151-8570東京都渋谷区千駄ヶ谷4-25-2） \\ E-Mail : kenmochi@fujita.co.jp \\ (前) 鉄道建設 - 運輸施設整備支援機構 鉄道建設本部 北陸新幹線建設局 \\ 2正会員 鉄道建設・運輸施設整備支援機構 鉄道建設本部 九州新幹線建設局 \\ （三812-8622福岡市博多区祇園町2-1）（前）同 北陸新幹線建設局 \\ 3 正会員 大成建設株式会社 土木技術研究所（广245-0051 神奈川県横浜市戸塚区名瀬町344-1） \\ 4正会員 大成建設株式会社 北信越支店土木部（广950-8585 新潟県新潟市八千代1-4-16） \\ 5正会員＼cjkstart株式会社大林組土木技術本部（干108-8502 東京都港区港南2-15-2）
}

\begin{abstract}
北陸新幹線飯山トンネルでは，著しい膨圧現象が発生したため支保工を二次，三次と分割して施工する 多重支保工法を適用した。 多重支保工法は，それぞれの支保工を適切に施工することにより掘削に伴う変 位を管理し変形余裕量内に地山の変位を制御する工法である. 施工ならびに計測結果を整理し三次元弾塑 性解析を実施することにより，二次支保工の一次支保工に対する役割，また二次支保工の支保工全体に対 する効果, および工法の特長が明らかになり, 多重支保工法が膨圧性泥質岩地山掘削工法として極めて柔 軟性に富み，安全で合理的であることを確認した。
\end{abstract}

Key Words : tunneling method, tunnel support, squeezing rock, argillaceous rock, support failure, three-dimensional numerical analysis

\section{1. はじめに}

北陸新幹線飯山トンネルは, 長野県と新潟県との県境 に位置する延長約 $22.2 \mathrm{~km}$ の長大トンネルである. 主な地 質は新第三紀中新世の泥質岩から成り, 膨圧現象の発生 が事前調査 ${ }^{1)}$ の段階より予測されていた. 図-1に示すよ うに同トンネルは6工区に分けて施工されているが，先 行する富倉工区で発生した膨圧現象に対し北川ら² は多 重支保工法を提案し適用した.

支保工を二重に施工する発想は，北陸新幹線朝日トン ネル東工区で実践されている3). これは, 切羽で重量化 した支保工を一度に構築できないため，支保工を分割し て施工したものである。しかし，著しい膨圧に遭遇した 鍋立山トンネルの切羽における剛性の高いセグメントに よる土圧計測結果では，土被り圧に等しい土圧が計測さ れ出たことから，大きな剛性と耐力を有寸る支保工は必 ずしも経済的ではない，また，実際に対応可能な支保部 材が用意できない場合も多い，

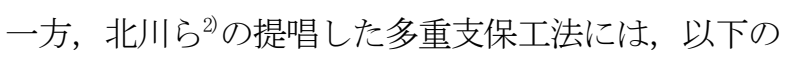
特徵がある.

1）掘削時に大きな変形余裕量を見込み，一次支保工 設置後の大きな変位と一次支保工の損傷を容認する.
これにより，地圧をある程度開放し二次支保工に作 用寸る荷重の低減を期待する.

2) 一次支保工の内側に二次支保工を施工寸る. 二次 支保工の応力を余裕のある状態にするために，切羽か らトンネル直径の3.5倍以上離した位置で二次支保工 を施工する.

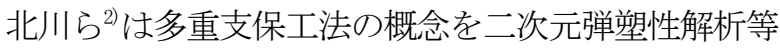
を用いて「縫返し」と同じ力学モデルで説明できるとし た. また，より激しい膨圧により一次支保工の段階で内 空変位量が300mmを大幅に越えるような場合は，その対 応を別途考慮する必要があると課題を挙げている.

飯山トンネルでは，富倉工区に引き続き木成工区，板 倉工区においても土被りの増加，地山の強度低下による 激しい膨圧を生ずる区間が出現した．地山の総変位量は 600mmを超え一次支保工は吹付けコンクリートの圧壊, 鋼製支保の座屈・破断など著しい損傷を受け，二次支保 工においてもクラックが発生して，内空限界に支障を生 じ，また，坑道を保持することが困難な状況が予測され た.このような厳しい施工状況下にある地山を掘削する ために多重支保工法の概念を，より発展的に明確化し定 量的な評価と具体的な適用方法を確立寸る必要があった。 本論文は，飯山トンネルにおける膨圧現象と施工結 


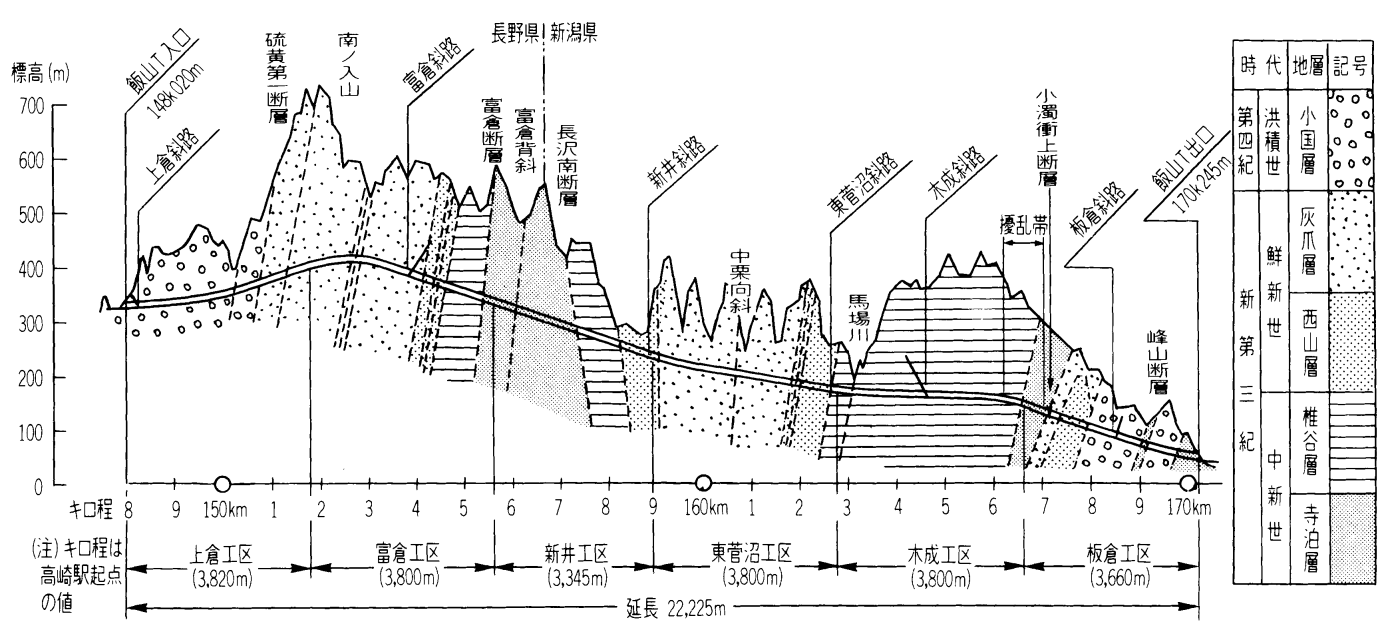

図-1 飯山トンネルの地質

果について分析し，支保を二重に施工する場合の特有な 現象について三次元弾塑性解析を実施して，二次支保工 のトンネル支保としての役割と効果について明らかにす ることにより多重支保工の合理性を述べ，「多重支保工 法の支保の手順」を提案するものである.

\section{2. 施工概要}

\section{(1) 地質}

飯山トンネルの地質縦断図を図-1に示す. 飯山トンネ ル付近の地質は，第三紀末期から第四紀初頭にかけて浅 海域が隆起し，次第に陸化した過程の堆積物で構成され る. 板倉工区を除く他の5工区の地質構造は，1 背斜軸 および 1 向斜軸よりなる明瞭な褶曲構造を呈している. 褶曲構造に沿う高角度の断層が多数発達しており, 断層 に沿うせん断帯が多くの個所に分布する. また，同トン ネルの北東 $30 \mathrm{~km}$ 付近には建設時に大きな膨圧性地圧が作 用し施工が著しく難淽した「ほくほく線の鍋立山トンネ ル4)5)」がある.

本章では，主に木成，板倉工区で発生した膨圧現象に ついて述べる. 木成工区は本坑全長 $\mathrm{L}=3,800 \mathrm{~m}$ で, 現在ま

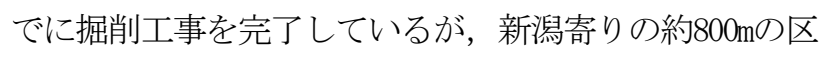
間で顕著な膨圧現象が生じ，また板倉工区は全長 $3,660 \mathrm{~m}$ で木成工区と隣接する長野寄り $400 \mathrm{~m}$ で同様な膨圧に遭遇 し，これらの区間のほとんどを多重支保工法により施工 している. 主な地質は, 新第三系中新統の椎谷層で, 泥 岩を主体とし砂岩, 凝灰岩が挟在する. 泥岩は主として 節理の発達した泥岩で層状に割れやすく，割れ目は鏡肌 化していることが多い. ボーリングコアおよび切羽付近 の岩片による一軸圧縮強度は，2～ $12 \mathrm{MN} / \mathrm{m}^{2}$ 程度で脆弱部 を有しており，湧水はほとんど見られない。また，土被 りは最大 $270 \mathrm{~m} て ゙$ 地山強度比は0.2〜2.50範囲にあり, 膨 圧の目安とされている2.06)を下回るケースが多い.

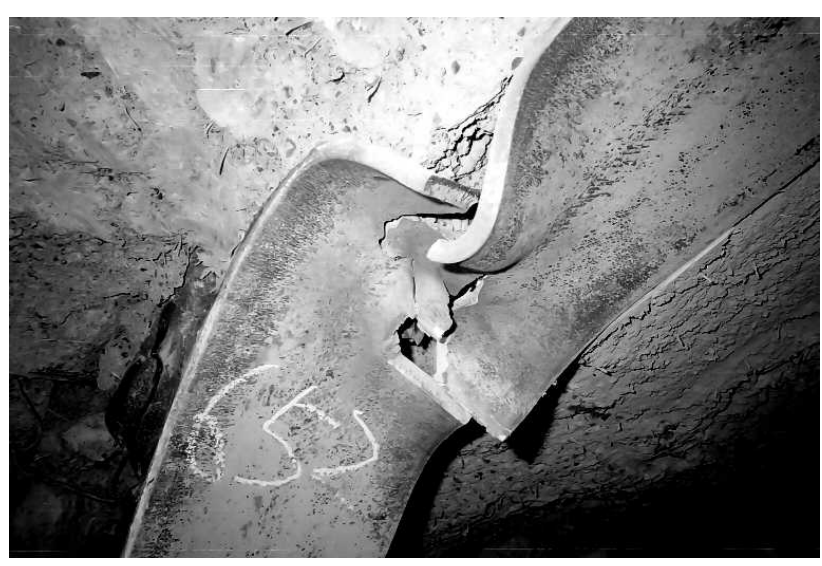

写真-1 上半支保工の肩部 $(165 \mathrm{~km} 230 \mathrm{~m}$ 付近)

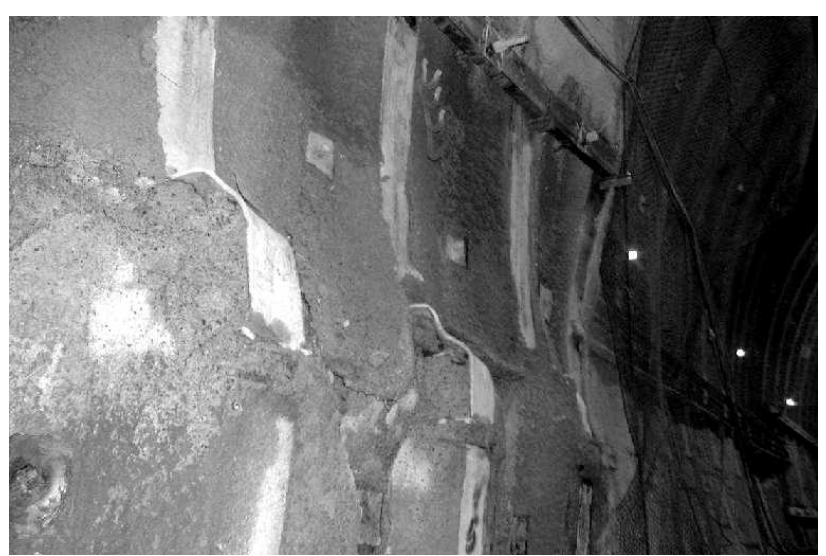

写真-2 上半支保工の根足部（166km960m 付近）

\section{(2) 一般区間の変位}

一般区間（一次支保工単独施工）の支保工の変状を写

\section{真-1, 写真-2に示す.}

鋼製支保工は上半，下半，インバートとも200Hを使 用した．吹付コンクリートは，各部とも最小厚 $25 \mathrm{~cm}$ （繊 維補強なし）で施工した. 掘削工法はミニベンチカット 工法 ${ }^{7)}$, 補助ベンチ付き全断面工法 ${ }^{7)}$ により掘削した. し 
かし, 岩盤の強度が低い脆弱層に遭遇すると変位量が大 きくなり, 変状が上半の天端, 局部（写真-1）および上 半根足部付近（写真-2）さらにインバート部で数多く発 生した。このような地山では変位速度が内空変位で約 $100 \mathrm{~mm} /$ day 程度と極めて大きいことが特徵である. 補助 工法として長尺ロックボルト，鏡止めボルト，フットパ イル等を施工したが，上半部掘削の段階で支保工脚部が 内空側に押し出され, 坑道の安全と内空確保のために縫 い返しを実施する区間が続くこととなった，変位量は最 大で縫い返し直前での内空変位量は約 $500 \mathrm{~mm}$, 縫い返し 後も約 $200 \mathrm{~mm}$ 発生し, 上半脚部の沈下量は $1000 \mathrm{~mm}$ 超え た. 一次インバートによる全断面閉合後, 変位は少しだ け収束に向かう傾向を見せるが，変位が拘束されること から支保工の応力は増加し, それまでなかった，あるい は小さかった変状が顕在化したり大きくなったり寸るケ ースがしばしば見られた。

上述のとおり膨圧性地山の掘削工法として従来から有 効とされてきた掘削工法, 各種の補助工法による対策で は, この椎谷層泥岩を主体とする膨圧性泥質岩地山の掘 削は困難であった.

\section{（3）多重支保工法}

図-2は標準的な多重支保工法の施工手順を示したもの である. 最初に変形余裕量を設定し，さらに，施工上必 要な上げ越し，広げ越しを含んだ掘削断面を決定する.

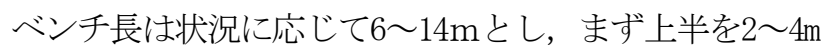
掘削し，続いて下半，一次インバートをそれぞれ $2 \sim 4 \mathrm{~m}$ ずつ掘削する. その後, 全断面にわたり二次支保工を施 工する.

図-3は代表的な支保パターンと仕様を示したものであ る. 同図の場合, 多重支保工を適用するための掘削のス ペースは, 半径方向で変形余裕量が $40 \mathrm{~cm}$ (一次 $30 \mathrm{~cm}+二$ 次 $10 \mathrm{~cm}$ : 図面上のみの区分)であり, その内側に二次支 保工 $(125 \mathrm{H}$, 吹付 $12.5 \mathrm{~cm})$ 相当部分として $12.5 \mathrm{~cm}$ が必要 となることから半径方向の合計で $52.5 \mathrm{~cm}$ となる.

一次支保工の仕様は「NATM設計施工指針 $\left.{ }^{8}\right\rfloor$ における 特殊地山を参考として設定した。吹付けコンクリートは 最小厚で管理し, 吹付け厚さは25cmとした. 吹付けコン クリートには, クラック発生後の耐力の急激な減少の抑 制と落下防止対策を目的として, 補強繊維（ポリプロピ レン繊維）を混入している. 鋼製支保工は $200 H$ とした. また，ロックボルトはトンネルの変形モードが鉛直方向 よりも水平方向が卓越していることから, 同図に示すよ うに, $\mathrm{L}=4.5 \mathrm{~m}$ 上半脚部付近と下半に重点的に配置して いる. 一次インバートは当初, 早強コンクリートを使用 し場所打ち施工としたが，盤ぶくれにより，その多くが 破損したためインバートストラット (200H) と吹付けコ
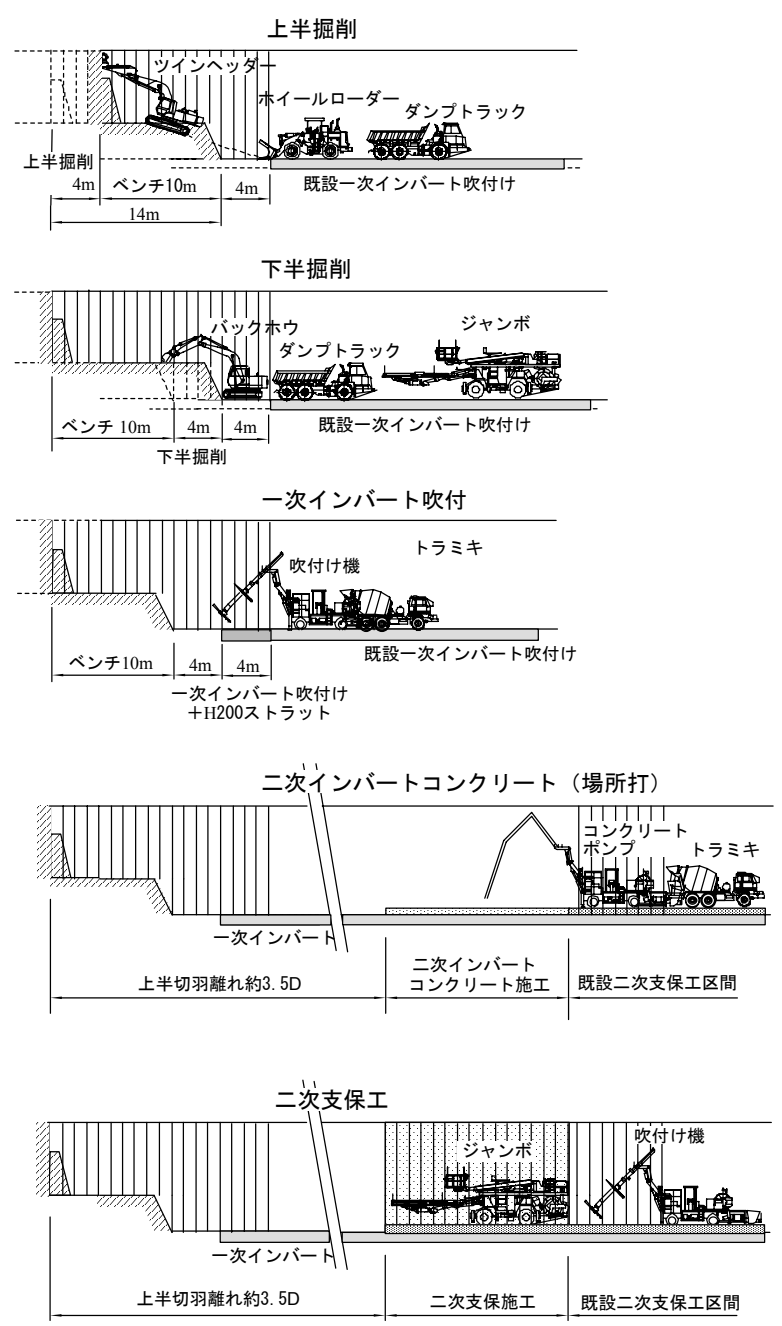

図-2 施工手順

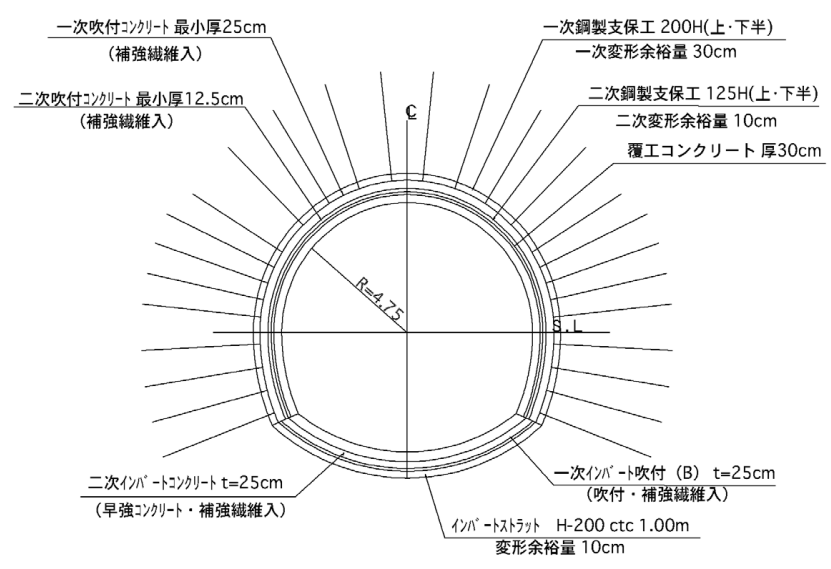

図-3 支保のパターンと仕様

ンクリート $25 \mathrm{~cm} （$ 補強繊維入り）のパターンに変更した. 二次支保工は一次支保工と比較して支保工を軽量化し ている.なお，本文における一次，二次支保工の仕様は 特に記載しない限り図-3と同一となっている. 


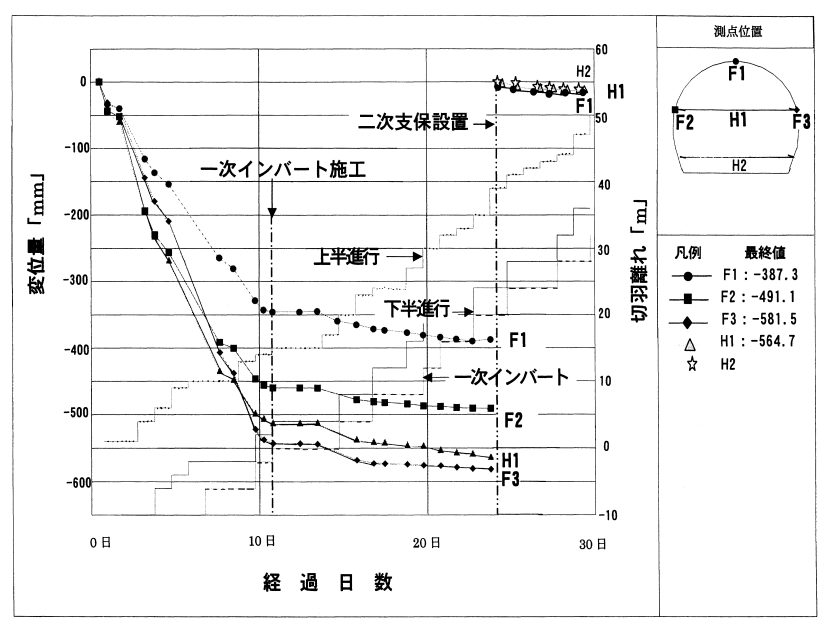

図-4 事例 $-1 \quad(165 \mathrm{~km} 170 \mathrm{~m})$

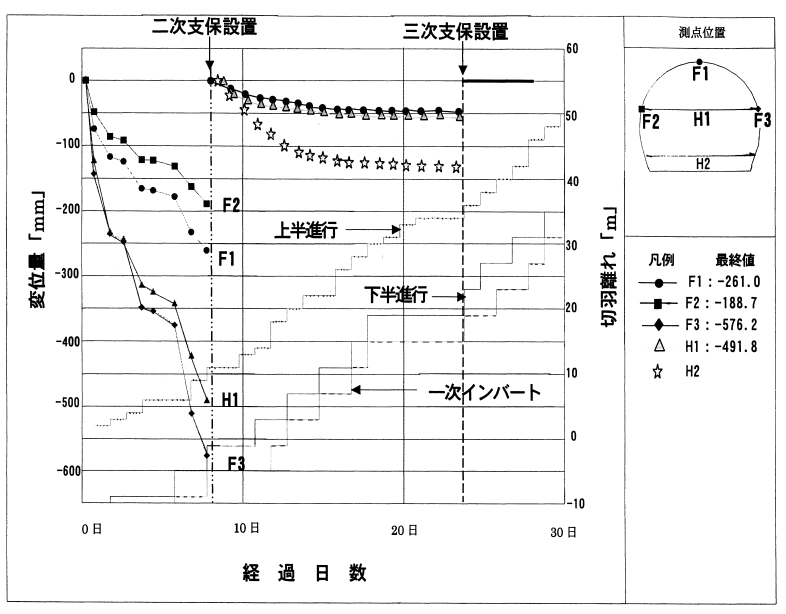

図-5 事例-2 (165km251m)

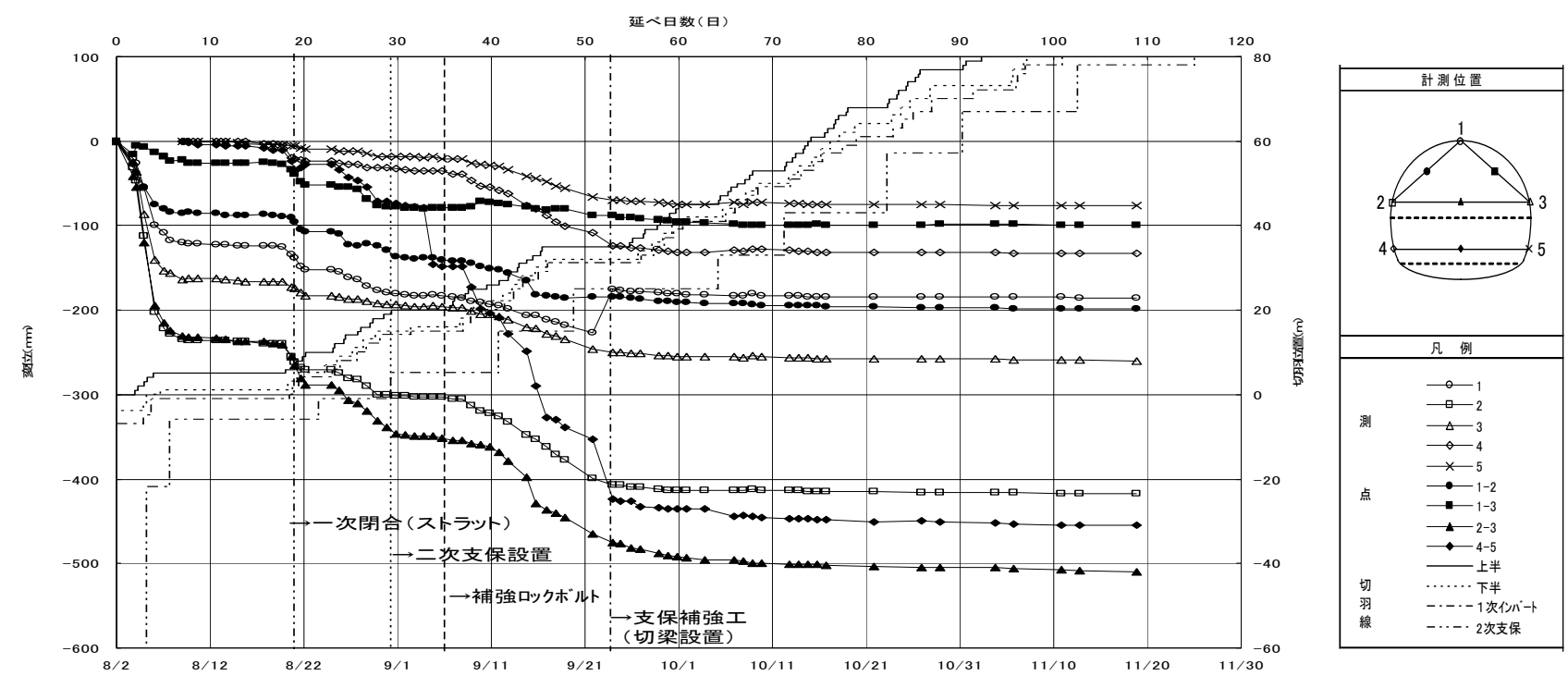

図-6 事例-3 (166km936m)

\section{3. 膨圧による支保工の変位}

当初，二次支保工は北川ら ${ }^{2)}$ の研究に基づき，その健 全性を確保するために切羽から 3.5D（Dはトンネル直径, $\mathrm{D}=10 \mathrm{~m} ）$ 以上離して施工寸るよう計画したが，膨圧の 増大により一次支保工の変状が著しいものとなった. 多 重支保工の変位発生状況について，その特徵を次の3つ の計測事例で説明する.

1）図-4に示す事例-1は二次支保工を切羽からの離れを 4. 2D (42m) で施工したものである. 地山は劣悪で膨 圧が発生しているものの，一次支保工の変位は比較的 滑らかに増加しており二次支保工の施工を待たずに上 半切羽からの離れが3D (30m) 付近で変位はほぼ収束 している.この結果，二次支保工では，ほとんで変位 が発生しない，掘削計画はベンチ長を1Dとし一次イン

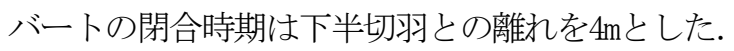

2) 事例-1に対し一次支保工の変状が急激に増大し, ト ンネルの安全を確保する必要から, 切羽近傍で二次支
保工を設置しなければならない状況が度々生ずること となった. 図-5に示寸事例-2は，一次支保工の吹付け コンクリートの剥離や鋼製支保工のフランジの変形等 により, 二次支保工を上半切羽からの離れが3.5D以上 になるまで待たずに1.1D（11m）で緊急に施工した事 例である. 一次インバートの施工までの掘削計画は事 例-1と同様である. 二次支保工施工後の内空変位は, 変位勾配が明らかに変化しており二次支保工による変 位の抑制効果が表われている.

ただし，この事例では下半の内空変位量は比較的 大きな值（100mm以上）を示し，二次吹付けコンクリ 一トにもクラックが発生したため, 引き続き三次支保 工（125H+吹付けコンクリート厚 $12.5 \mathrm{~cm} ）$ を施工して 支保の安定を図った. 三次支保工施工時の切羽からの 離れは3.3D（33m）である. 事例-2は二次支保工の施 工により変位の抑制がうまくいった例である.

3）図-6に示寸事例-3は，より不良化した擾乱帯と呼ば れる地山における計測結果である. ベンチ長は0.5Dとし 
一次インバートは下半掘削後ただちに閉合する計画とし た.この事例では, 事例-2と同様にトンネルの安全確保 のために二次支保工の施工を早め, 切羽からの離れを 2. OD $(20 \mathrm{~m})$ に変更したものであるが吹付けコンクリー 卜の圧壊，鋼製支保工の座屈や破断など，一次支保工の 受けた損傷は著しいものであった. 二次支保工の施工後 に，変位が収束する傾向がみられたが，切羽の進行に伴 い再度, 変位が増加した. 留意すべき点は地山を支保す べき二次支保工が機能しなかったことである.

表-1 に各事例の計測実績を示す．初期変位速度はい ずれも $10 \mathrm{~cm} /$ day を超えている. また, 事例-3 の二次変 位量はかなり大きい. 事例-1３ の一次支保工および 二次支保工の支保パターンとその仕様は図-3 に示した とおりであり, ロックボルトの本数に若干の差があるも ののほぼ同一と考えて良い.

以上のとおり，地山条件が格段に厳しくなる飯山トン ネルの膨圧性泥岩トンネルを確実に掘削するためには, 多重支保工法における変形余裕量の設定，一次および二 次支保工の適切な仕様，二次支保工の施工時期の決定等， 具体的な施工方法の検討が重要な課題であった.

\section{4. 多重支保工法の特徵}

\section{(1) 変位}

まず，変位量と二次支保工施工位置の関係について 述べる. 使用したデータは多重支保工を施工した全区間 を対象としている.

「変位量」は特に記載しない限りは上半内空変位量 を示し，一次支保工だけの場合の「一次変位量」と二次 支保工の施工後に発生した「二次変位量」と，それらの 合計である「総変位量」とを用いている．これらの変位 量は, 縫返し施工による変位量は含まない。 また, 二次 支保工施工時の上半切羽からの距離はトンネル直径 （10m）であるDを用いて表している（以下，これを切羽 離れと呼ぶ)。

図-7は総変位量と二次支保工施工時の切羽離れの関係 を示したものである. 同図中の $\mathrm{A}$ 部， B部，C部は次の とおりである.

1）A部は一次支保工の変状を許し，切羽離れが $3.5 \mathrm{D}$ 以 上離れた後ほぼ変位の収束を待って二次支保工を施工 したもの（図-4 事例-1)

2）B部は一次支保工の変位速度が大きく, 支保工に変 状が発生したため, トンネルの安定を確保するととも に変位の制御を目的として二次支保工の施工時期を早 めたもの（図-5 事例-2）
表-1 計測実績（内空変位量）

\begin{tabular}{|c|c|c|c|c|}
\hline & & $\begin{array}{c}\text { 事例-1 } \\
165 \mathrm{~km} 170 \mathrm{~m}\end{array}$ & \begin{tabular}{|c|} 
事例-2 \\
$165 \mathrm{~km} 251 \mathrm{~m}$ \\
\end{tabular} & $\begin{array}{c}\text { 事例-3 } \\
166 \mathrm{~km} 936 \mathrm{~m}\end{array}$ \\
\hline 初期変位速度 & 「mm/日」 & 105 & 120 & 120 \\
\hline 一次変位量 & $\lceil\mathrm{mm}\rfloor$ & 565 & 494 & 350 \\
\hline 二次変位量 & $\lceil\mathrm{mm}\rfloor$ & 24 & 50 & 161 \\
\hline 総変位量 & {$[\mathrm{mm}\rfloor$} & 589 & 544 & 511 \\
\hline 二次設置時の切 & からの離れ & $4.1 \mathrm{D}$ & $1.1 \mathrm{D}$ & $2.0 \mathrm{D}$ \\
\hline \multicolumn{2}{|c|}{ 備 考 } & & \begin{tabular}{|l|} 
三次支保工 \\
変位量 $\quad 4 \mathrm{~mm}$ \\
\end{tabular} & \\
\hline
\end{tabular}

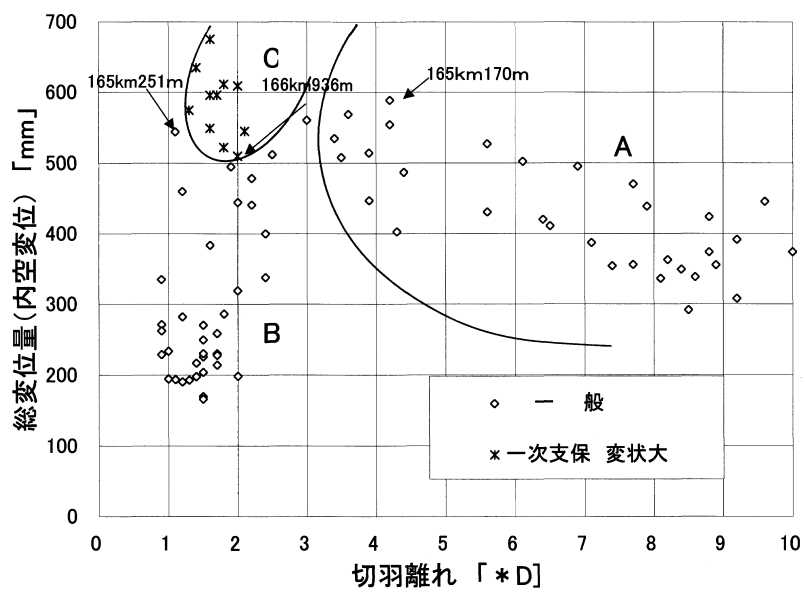

図-7 二次支保工の施工位置が総変位量に与える影響（1）

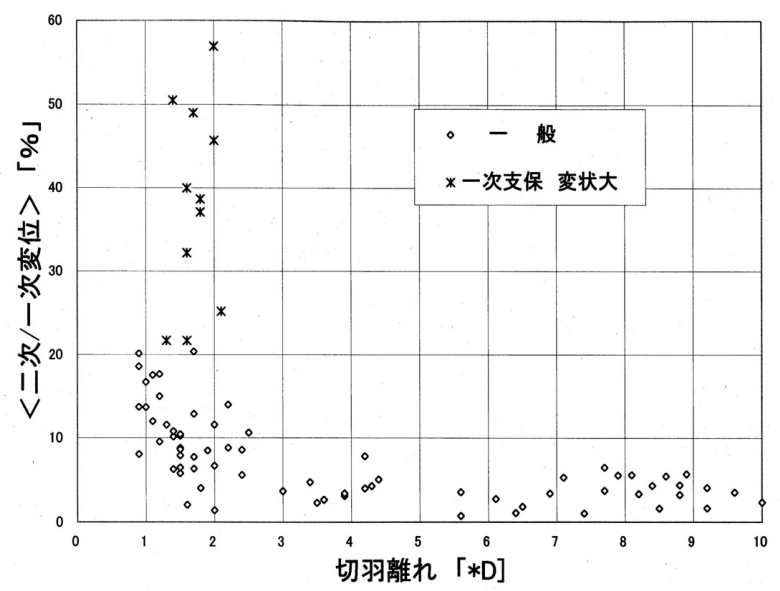

図-8 二次支保工の施工位置が二次変位量に与える影響 (1)

3） C部はB部と同様の考え方で施工したが，吹付けコ ンクリートの圧壊，鋼製支保工の破断等，目視でも明 かな著しい変状が発生したもの（図-6 事例-3)

これらの分類において，支保に著しい変状が発生した $\mathrm{C}$ 部の総変位量は, 変位をある程度許容した $\mathrm{A}$ 部よりも 大きく, B部の総変位量は両者と比較して小さい. なお, 二次支保工は施工効率上ある程度まとめて施工（一施工 スパン, 平均約 $12 \mathrm{~m}$ ) するため, 施工時の切羽からの離 れは一定とはなっていない. また，A部の二次支保工施 工時の切羽離れが $4 \mathrm{D} \sim 10 \mathrm{D}$ に広がっているのは, 一次支 保工が変状はあるものの安定しており, 主に施工性の理 由から二次支保工の施工時期を決定したためである. こ 
れらは膨圧が相刘的にみて，それほじ大きくなかった， あるいはその発生が急激でなかった地山である。

図-8 は二次支保工の施工位置と二次変位量の関係を 示した図である. 二次変位量は各断面に地山条件の違い があるため, 一次と二次変位量の比で示した. 二次支保 工施工時の切羽離れが大きくなると二次変位量は小さく なる. 切羽離れ $3 \mathrm{D}$ 以上で発生している変位量は, バラ ツキがあるものの, 本泥岩の持つクリープ変形によるも のと考えられる.

次に一次支保工に変状が発生したが，二次支保工は ほぼ健全であったB部について述べる.

一次変位量は, よく知られているトンネルにおける 切羽位置と変位量との関係と同じであり, 図-9 に示す とおり二次支保工の施工時の切羽離孔が増加するととも に増加している。

二次変位量は，図-10 に示寸とおり，一次変位量とは 異なり二次支保工施工時の切羽離れ距離が増加寸ると減 る傾向にある. ただし, その変位量は一次変位量と比較 して約 1/10 程度であり適切な時期に二次支保工を施工 したことにより小さくなっている.

総変位量は, 図-11 に示寸とおり, 二次支保工施工時 の切羽離れ距離が増加すると大きくなる.

また，これらの図中で*印（C 部再掲）で表している 一次支保工の著しい損傷は, 一次変位量が約 $400 \mathrm{~mm}$ 程度 以上, 二次変位量が約 $50 \mathrm{~mm}$ 程度以上, 総変位量が約 $500 \mathrm{~mm}$ 程度以上の断面で発生しており, 二次支保工施工 時の切羽離孔が 1.5D から 2D であることが特徴である. このような変状は一次変位量が過大で, 応力伝達のため に必要な一次支保工のスムーズな軸線が破壊されたため, 二次支保工の施工が効力を発揮せず，支保工全体として 変位の制御能力を失ったことによるものと考えられる。

対策は一次変位量の低減のための二次支保工の早期 の施工である. また, 状況により一次支保工の高規格化 が図られなくてはならない，なお，二次支保工の健全性 を確保するために必要なことは，二次支保工の施工時の 切羽離れを十分に確保するのではなく, 逆に早期の施工 を実施することであり，その結果として一次支保工，二 次支保工の変位量を共に低減できることとなる.

一般に吹付けコンクリートにクラックが発生する変 位量は, 全断面閉合までの日数, さらにトンネル各部の 変位分布やその大きさによっても影響を受け，乙れを明 確にすることは困難である．しかし，飯山トンネルの施 工実績では, 内空変位量が $200 \mathrm{~mm} \sim 300 \mathrm{~mm}$ となると一次 吹付けコンクリートに明瞭にクラックが発生し， $400 \mathrm{~mm}$ を超えると吹付けコンクリートの剥離, 鋼製支保工フラ ンジの変形などが生じ，さらに変位が $500 \mathrm{~mm}$ を超えると 吹付けコンクリートのせん断破壞，鋼製支保工の破断等，

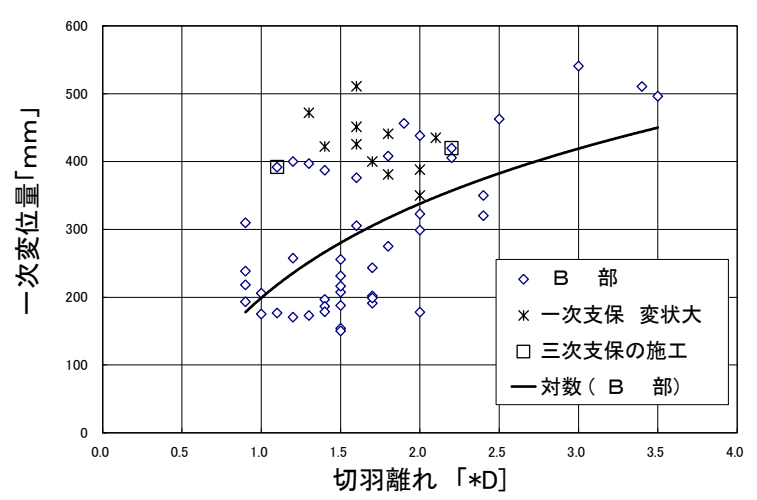

図-9 二次支保工の施工位置が一次変位量に与える影響

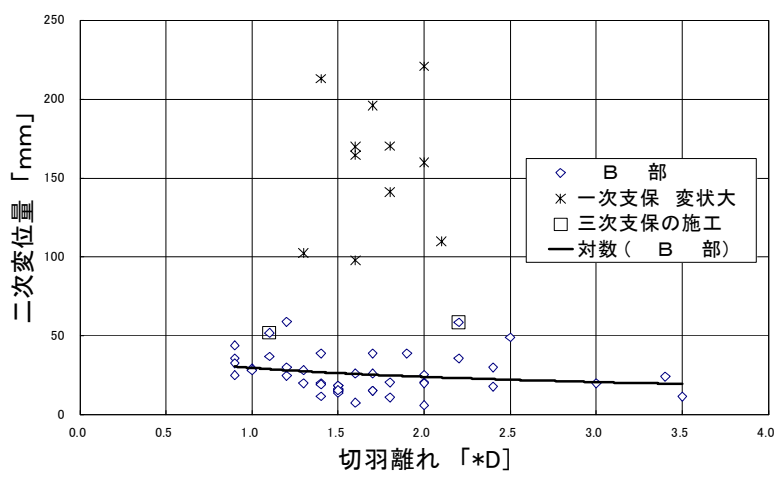

図-10 二次支保工の施工位置が二次変位量に与える影響 (2)

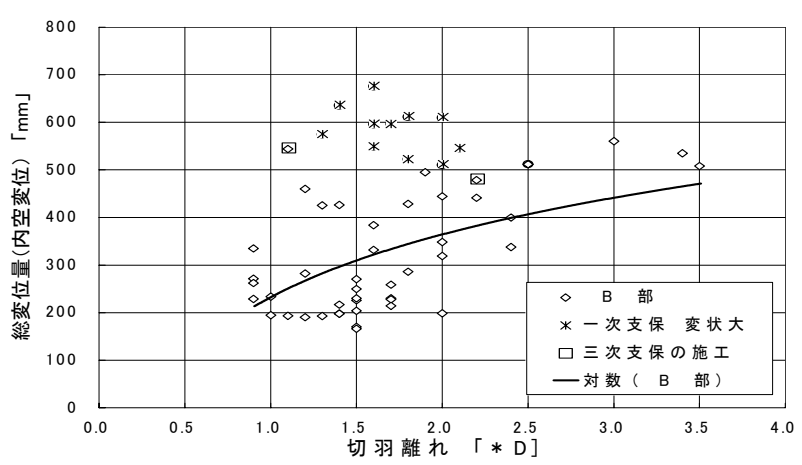

図-11 二次支保工の施工位置が総変位量に与える影響 (2)

著しい変状が発生している. 一方，二次支保工の施工実 績では, 内空変位が約 $50 \mathrm{~mm}$ 以上となると吹付けコンク リートにクラックが発生している. このクラックの発生 における一次支保工と二次支保工の内空変位量の比率, 1/4 1/6 は，二次支保工では断面の閉合が施工と同時 に完結するとともに付着対象が地山より強固な一次吹付 けコンクリートであることから一次支保工に比較して変 形係数が大きくなっていることによるものと思われる.

これらの検討結果を整理すると，1）二次支保工の施 工は切羽からの離れをもとに実施するのではなく, 一次 変位量により, その施工時期が決定されなくてはならな い，2）而压構造物としての一次支保工の円滑である心゙ き形状が侵される兆候があるときは，速やかに二次支保 


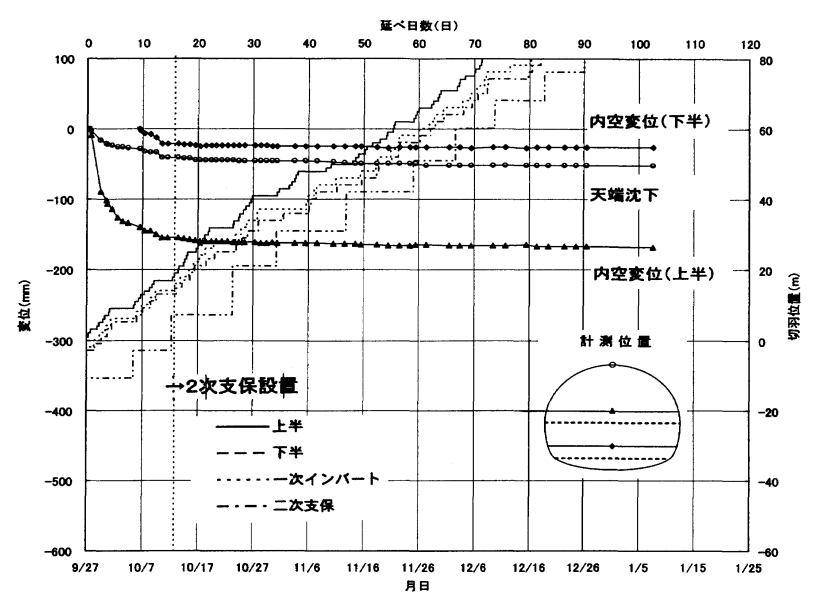

図-12 変位の経時変化（166km901m付近）

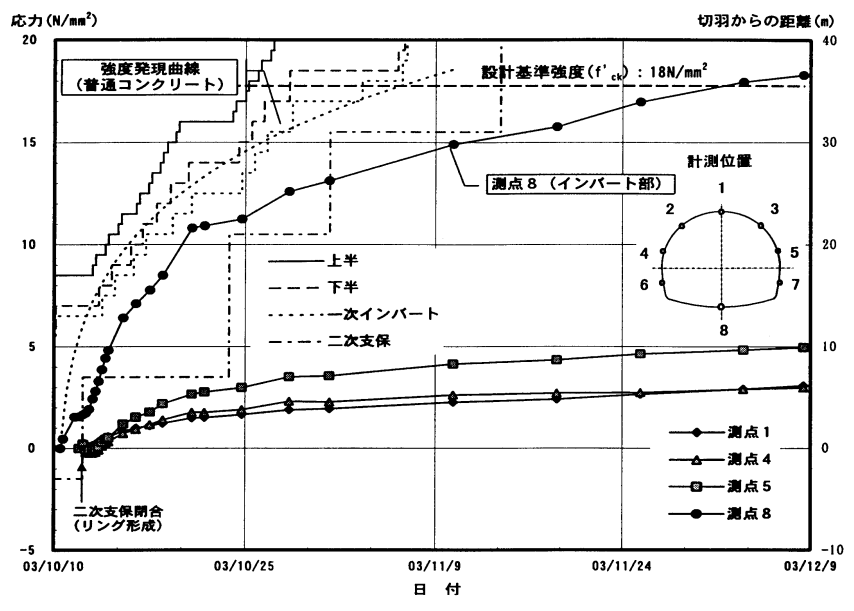

図-14 二次吹付けコンクリート応力（166km901m 付近） 計測位置

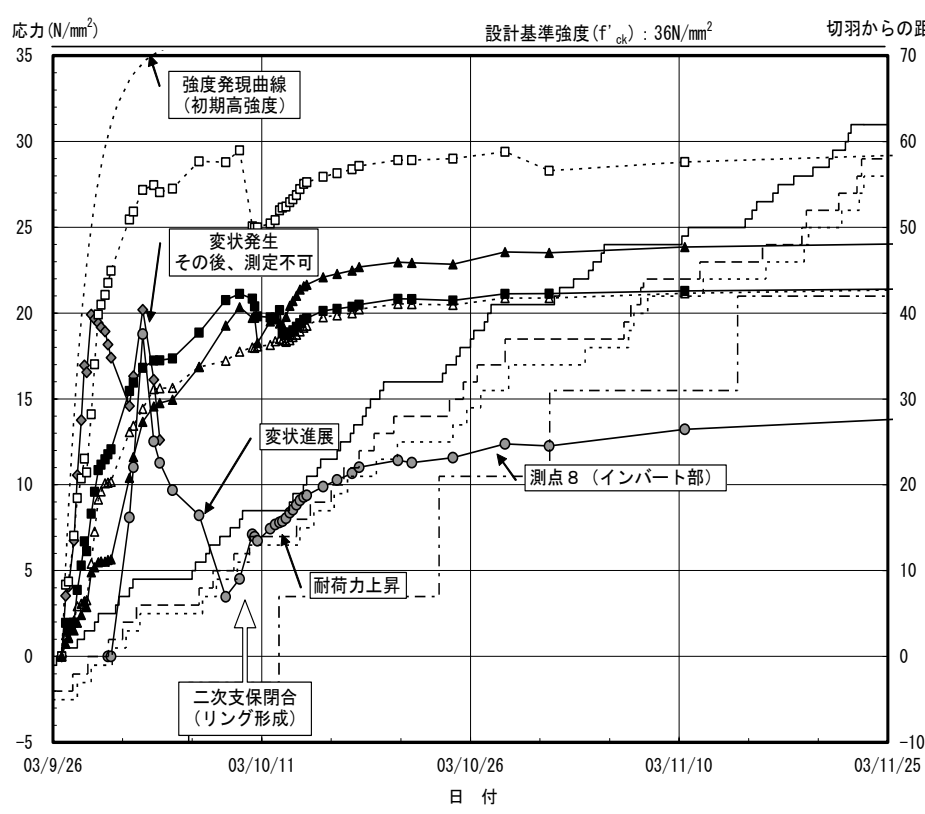

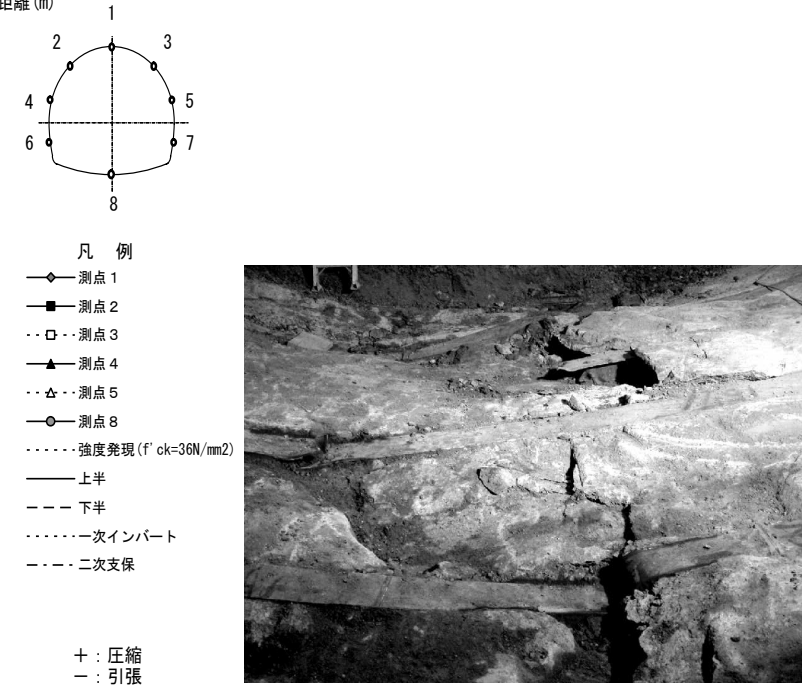

写真-3 インバート中央変状 $(166 \mathrm{~km} 910 \mathrm{~m})$

図-13 応力の経時変化（166km901m 付近）

工を施工する必要がある，3）これらによる二次支保工 の施工は総変位量の低減に有効であった，4）一次支保 工は変位量として約 $300 \mathrm{~mm}$ 程度を許容の目安とするのが よい，5）二次支保工の変位量は地山の弾塑性的挙動と 長期的な変位を考慮して約 $50 \mathrm{~mm}$ 程度以下となるよう管 理することが適切と思われる，となる.

\section{(2) 二次支保工の効果}

図-12 は，166km901m の変位の計測結果を示したもの である. 二次支保工施工時の切羽離れは $1.8 \mathrm{D}$ であり， 良好に変位制御された断面である.

同断面における一次支保工の吹付けコンクリート応力 測定結果を図-13 に示す. 応力の測定は荷重計型のコン クリート有効応力計を使用した. 各計測点において応力 は急激に上昇するが，各点ともクラックの発生によるも のと思われる応力の減少がみられる. 特にインバート部 においては, クラックの発生に伴い応力が急激に減少し
ている. 注目すべき点は，二次支保工の施工後に一次 吹付けコンクリートの各測点において, 残存していた応 力が反転し, 再上昇していることである. 後述する数值 解析の結果はこの吹付けコンクリートの応力測定結果の 傾向をよく説明している.

続いて，同断面の二次支保工の吹付けコンクリートの 応力測定結果を図-14に示す. 各測点とも, 応力が滑ら かに増加しインバート部のみ応力が設計基準強度に達し ている. 写真-3は一次インバート部分の変状の例である.

トンネルを円形と仮定した以下の算式により，各支 保部材の計測結果を利用して, 支保の換算内圧を求める ことができる.すなおち鋼製支保工および吹付けコンク リートによる内圧 $P_{i}$ は

$$
P_{i}=\left(\sigma_{s} t\right) / r
$$

ここに， $\sigma_{s}$ は部材応力 (計測值平均),$t$ は単位奥行き あたりの断面積, $r$ はトンネル半径である.

またロックボルトの軸力 $R_{b}$ は, 


$$
R_{b}=\sigma_{t} / S
$$

ここに, $\sigma_{t}$ は部材の応力 (各測点の最大值の平均),$S$ は 1 本あたりの打設面積（ロックボルトの周方向ピッチ ×縦断方向のピッチ) である.

図-15 は 166km901m の各支保工の換算内圧とそれらを 合計した換算内圧の経時変化を示した図である，換算内 圧は徐々に増加し, 一次支保工の閉合後に, 部分的と思 われるクラックの発生により増加傾向は鈍るものの二次 支保工の施工により再度増加に転じる様子がわかる. 各 支保工を合計した換算内圧は二次支保工施工直前に対し て約 25\%程度増加している.

本工法のように超膨圧下で掘削するトンネルの変位制 御には，吹付けコンクリートの役割が大きい，特に材齢 初期の強度発現は重要であり, 新材料の開発とそれらの 支保としての作用効果の検討が必要であると考えられる. また，ロックボルトは $70 \mathrm{~cm}$ ピッチで一断面あたり 34 本 と相当の本数を打設しているが，本計測結果による換算 内圧では，それらの寄与率は約 $9 \%$ とさほど高くない. この点についても，別途，検討すべき課題と考えている. なお，当該部分は一次支保工における吹付けコンクリ 一トにエトリンガイト系混和材を使用して, 降伏強度を $36 \mathrm{~N} / \mathrm{mm}^{2}$ に増加し（以下，高強度吹付けコンクリートと 呼ぶ），鋼製支保工の使用鋼材を SS540 に変更すること による一次支保工の高規格化を試行した区間である。

\section{5. 多重支保工法の効果に関する数値解析}

試験施工や計測などにより，現場の施工で確認できる 現象には限界がある，そこで，数值解析により，多重支 保工法を施工した際に生じる現象について予測を行い， その理解を深めることが重要である.

著者らは，飯山トンネルにおける一次支保工の変状を 伴う地山と支保の変形挙動について, 三次元弾塑性解析 により計測結果を良好に表現できることを示した9). こ の中で, 切羽や坑壁周囲に塑性領域が大きく発達寸る場 合には，その状態を掘削解放率を用いた二次元解析2で は定量的に表現することができず，三次元の取り扱いが 必要になることを示した.

本章では, 地山の物性值や支保工の剛性を変化させ, 多重支保工特有の挙動について検討する.

\section{（1）解析条件}

解析に使用した地山と支保工の物性值を表-2に示寸。 地山の物性值は，B計測を実施した $165 \mathrm{~km} 200 \mathrm{~m}$ 付近を対象 として設定した地山-19) と, さらに不良な状況を想定し た地山-2の 2 種類とした．地山-1は総内空変位量で約

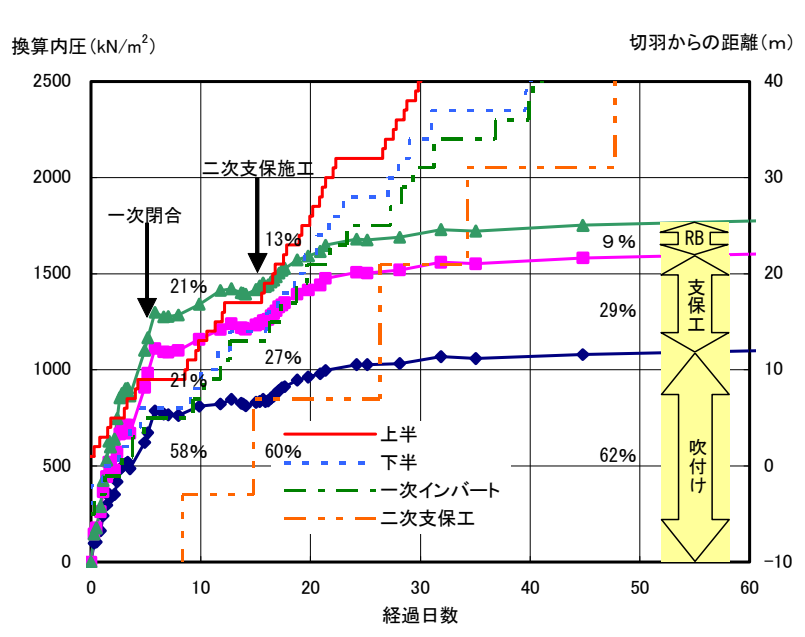

図-15 支保部材の換算内圧

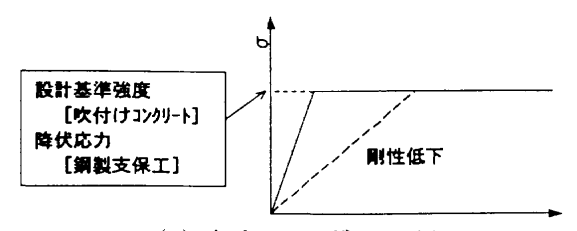

(a) 応力ーひずみ関係

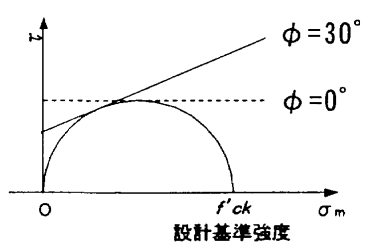

(b) 降伏関数（吹付けコン夘ートのみ）

図-16支保モデル

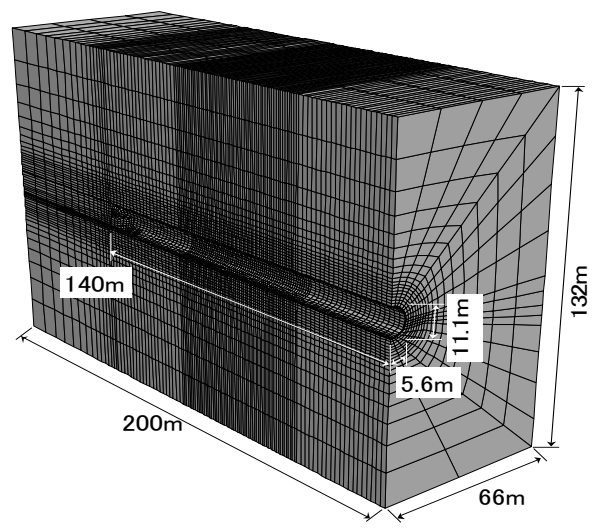

図-17 三次元解析モデル

表-2 地山と支保の物性值

\begin{tabular}{|c|c|c|c|c|c|}
\hline & $\begin{array}{c}\text { ヤ゙グ率 } \\
\text { [GPa] }\end{array}$ & ポアアン比 & $\begin{array}{l}\text { 粘着力 } \\
\text { [MPa] }\end{array}$ & \begin{tabular}{|c} 
内部摩擦䏍 \\
[度]
\end{tabular} & $\begin{array}{l}\text { 降伏応力 } \\
\text { [N/mm2] }\end{array}$ \\
\hline 地山上1 & 0.3 & 0.3 & 0.40 & 20.0 & - \\
\hline 地山上2 & 0.2 & 0.3 & 0.26 & 16.5 & - \\
\hline \multicolumn{6}{|l|}{ ， ）通常 支保(剛性1/5) } \\
\hline 吹付けコンクリ一厚 $25 \mathrm{~cm}$ & $3.4(0.68)$ & 0.2 & 9.0 & 30.0 & - \\
\hline 鋼製支保工 250H & $200(40)$ & - & - & - & 235.0 \\
\hline \multicolumn{6}{|l|}{ ii)高規格支保(剛性1/5) } \\
\hline 高強度吹付けコンクリ一ト厚 $25 \mathrm{~cm}$ & $6.8(1.36)$ & 0.2 & 18.0 & 30.0 & - \\
\hline 高耐力鋼製支保工 250H & $200(40)$ & - & - & - & 390.0 \\
\hline
\end{tabular}




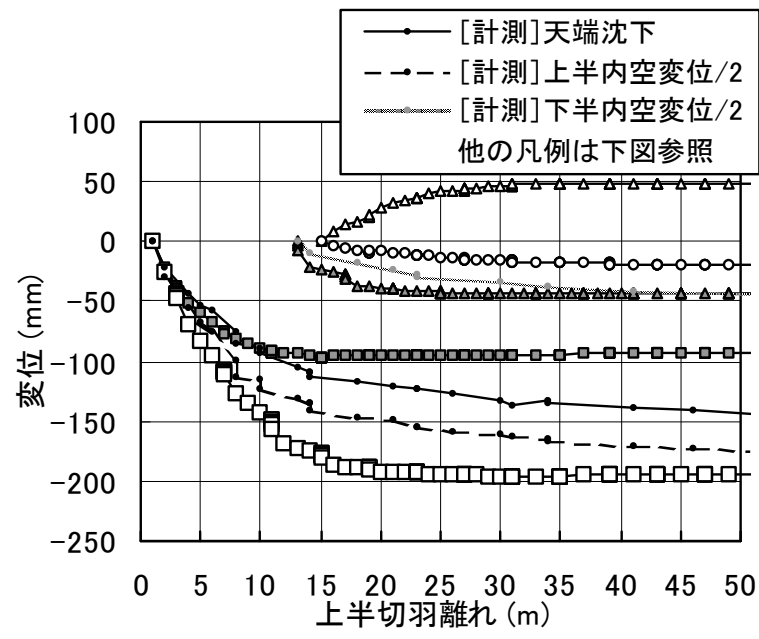

(a) 掘削パターン $1<3.4 \mathrm{D}>$

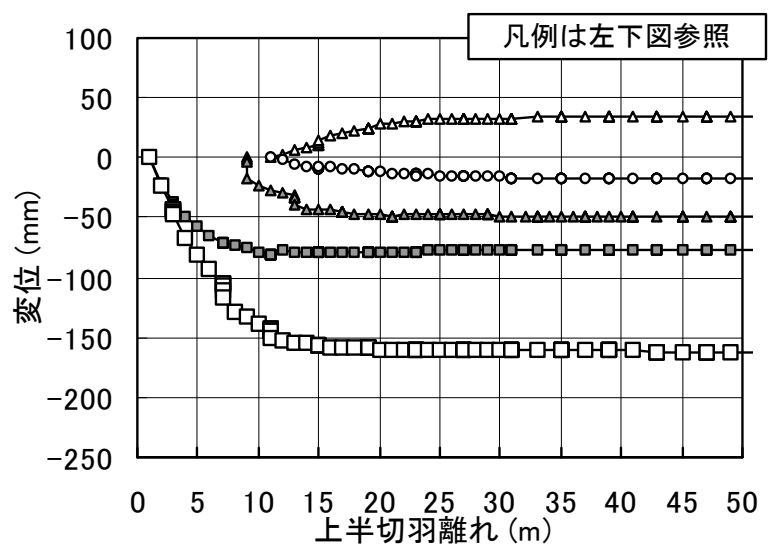

(b) 掘削パターン $2<1 \mathrm{D}>$

図-18 天端沈下と坑壁水平変位 (総変位量)

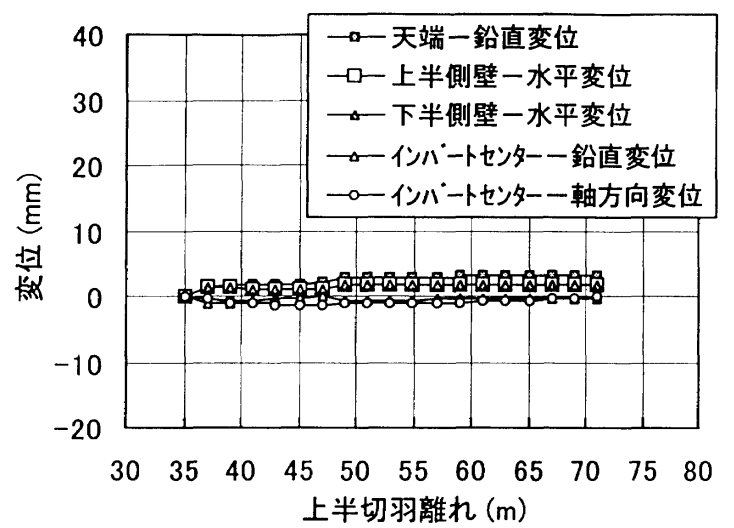

(a) 掘削パターン $1<3.4 \mathrm{D}>$

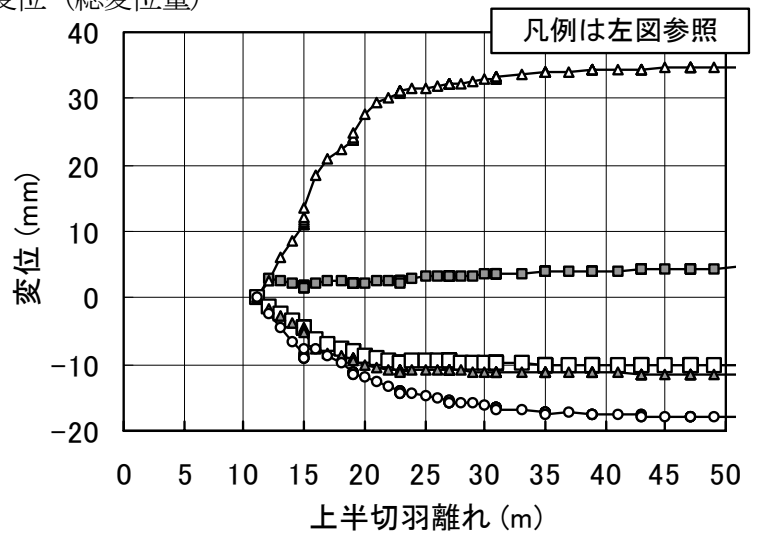

(b) 掘削パターン $2<1 \mathrm{D}>$

図-19 天端沈下と坑壁水平変位 (二次変位量)

400mm程度の地山である。同計測では，地中変位量より 算出した坑壁周囲の区間ひずみが切羽前方からそれまで に生じた先行ひずみを含まないにもかかわらずボーリン グコアによる限界ひずみを大きく上回っている゙ ことか ら解析においては地山は塑性化するものとし，その取扱 いは簡明なMohr-Coulombの降伏規準に従う完全弾塑性体 とし，塑性変形時の体積変化はないものとした。

支保工の物性值は一般によく使用しているi）通常と， 比較検討のためのii）高規格の 2 種類とし物性值は 「NATM設計施工指針 ${ }^{8)} 」$ を基本として設定することとし た。ただし，一次支保工は支保と地山とのなじみを考慮 して両者とも支保工の剛性を $1 / 5$ とている9．また，支 保工の降伏現象を表すために，鋼製支保工については， 軸力により降伏する一軸の棒要素を連結し, 吹付けコン クリートについては, Mohr-Coulomb型の弾塑性体のソリ ッド要素を用いてモデル化した。 ここでは，図-16に示 すように一軸圧縮強度を基準に，せん断抵抗角を $\phi$ $=30^{\circ}$ とした. 既報9)では吹付けコンクリートが一軸圧縮 状態で降伏する挙動を重視して， $\phi=0^{\circ}$ としたが本研
表-3 掘削・支保施工パターン

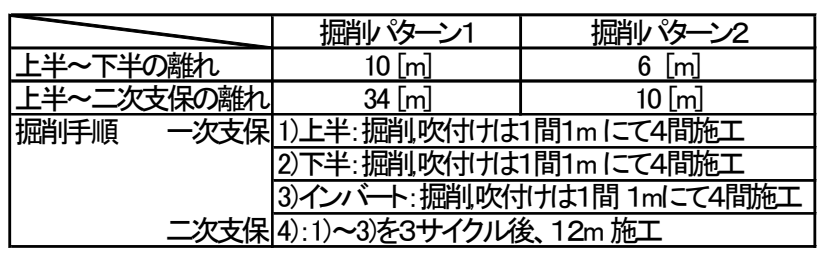

究では二次支保工の施工が一次支保工に与える内圧の効 果をみるために $\phi=30^{\circ}$ としている. なお，一次支保工 のみの場合には，このモデル化でも既報9)とほとんど同 じ結果が得られることを確認している.

表-3に掘削手順および支保工の施工パターン 1 と 2 を 示す。三次元弾塑性解析には有限差分法コード10)を使用 した. 図-17は解析に使用した三次元地山モデルの外観 を示した図である. 図中の各境界面はローラー固定支持 とした。 トンネル天端部の土被りは260m, 地山の単位体

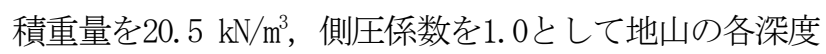
に対し自重相当の初期応力を与えた. また，上面にはそ の深度の土被り相当の上載圧を作用させた. 


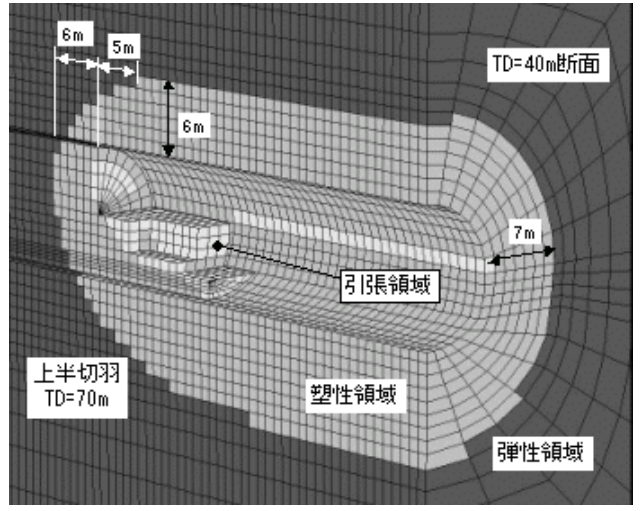

(a) 掘削パターン 1 切羽離れ 3. 4D

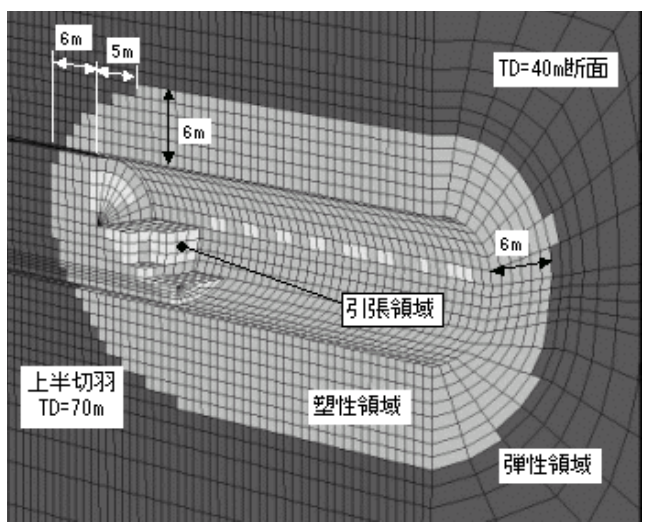

(b) 掘削パターン 2 切羽離れ $1 \mathrm{D}$

図-20 地山の塑性領域

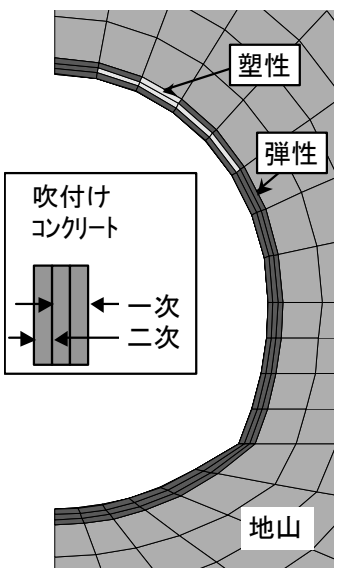

(a)切羽離孔 3.4D

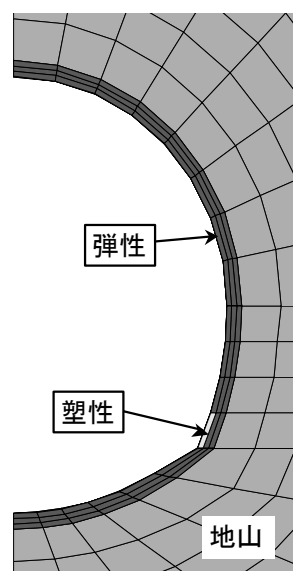

(b) 切羽離れ 1D
図-21 吹付けコンクリートの塑性領域

\section{（2）二次支保工の施工位置}

地山の物性值は地山-1を，支保はi）通常を使用して 解析した一次支保工各部の変位量 (総変位量) を図-18 に示寸. 解析結果は切羽前方の変位量を除外し, 切羽と の離れ1mの位置を計測開始点と考えその変位量が零とな るように換算した．また，図中では計測結果の内空変位 を解析結果の水平変位に対応させて半分の量で表してい る. 水平変位は内空縮小方向を負, 天端沈下およびイン バートセンターの鉛直変位は沈下を負とした．切羽離れ 3.4 D (34m) で二次支保工を施工する掘削パターン 1 の 解析結果は上半切羽との離れが $(10 \mathrm{~m})$ 程度までは計測 結果を概ね表現できているが，計測結果は上半切羽との 離れが1Dより離れても，ゆっくり増加を続け3.5Dでも収 束していない。これは地山が弾塑性挙動の他に量は小さ いもののクリープ変形挙動をしているためと推定される.

解析により得られた総変位量はいずれの部分におい ても3.5D付近にいたるまでにほぼ収束するため，切羽離 れ3.4Dで施工した二次支保工にはほとんど变位が発生し

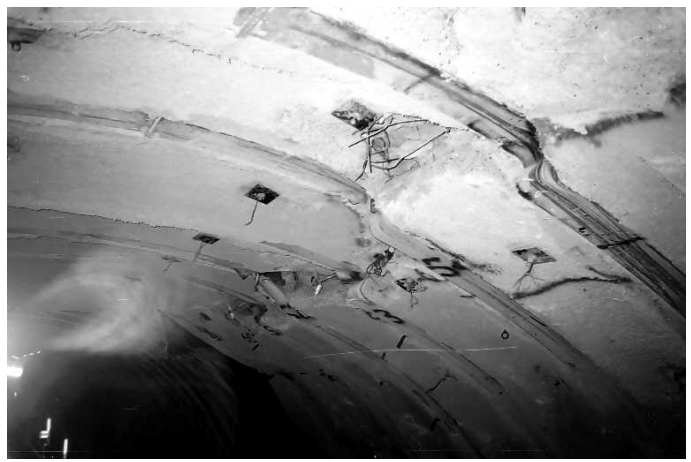

写真-4 一次支保肩部付近変状（165km230m 付近）

ない. 上半内空の一次変位量は $398 \mathrm{~mm}$, 二次変位量は $2 \mathrm{~mm}$ という結果である. 一方, 図-19に示寸切羽離れ1Dで二 次支保工を施工した掘削パターン 2 の解析結果は, 上半 内空の一次変位量は $305 \mathrm{~mm}$, 二次変位量は $18 \mathrm{~mm}$ であり, 各部における一次変位量は切羽離れ3.4Dの場合と比較し て小さくなっている. ただし，二次変位量は支保工を早 期に施工寸ることにより各部とも変位が増加しており, 特にインバート中央部では大きくなっている.

図-20にはトンネル周囲の地山に発生した塑性領域の 分布に関する解析結果を示したものである. 最も濃色の 部分は弾性領域, 灰色の部分は塑性領域を示寸.また, 図で「引張領域」と矢指した最も薄い灰色の部分は，引 張破壊が生じた部分である. 同図のTDは三次元解析モデ ル（図-17）の境界面からの距離を示している，掘削パ ターン 1 (3. 4D) と掘削パターン 2 (1D)では, 二次支保工 の施工時期の他に上半ベンチ長が異なるが，切羽

$(\mathrm{TD}=70 \mathrm{~m})$ 近傍では塑性領域の広がりに両者の差異はほ とんどない，一方，切羽から $30 \mathrm{~m}$ 離れた断面（TD=40m） 
では, 切羽離れ3.4Dが1Dよりも坑壁側方および底盤下方 での塑性領域が1mほどずつ広がっている結果が得られて おり，二次支保工の早期の施工が塑性領域の拡大を抑制 する効果を示しているものと考えられる.

吹付けコンクリートの塑性領域を図-21に示す。この 図は切羽から十分に後方の断面の解析結果である. 切羽 離れ3.4Dの一次支保工の肩部に塑性化した部分が現れる が，二次支保工は健全である. この一次支保工の塑性領 域は実施工における変状（写真-4）をよく表現している. これに対し1Dでは一次支保工に塑性化する部分がなくな り, 弾性状態を保っている. これは二次支保工を早期に 施工寸ることにより二次支保工が応分の応力を分担して いることによるものと考えられる. なお，1Dにおける二 次支保工の下半脚部にみられる塑性領域はトンネル軸方 向の二次支保工の打継ぎ目部分に限定して発生している ものである.

\section{（3）二次支保の効果}

地山の物性值は地山- 1 よりもさらに不良な地山-2を， 支保工はi）通常を使用し，掘削パターンを 2 （二次支 保工は1Dで施工）として解析した一次支保工上半部の吹 付けコンクリート応力の変化を図-22に示寸.この図は 二次支保工が切羽離れ $12 \mathrm{~m}$ で施工された断面であり, 天

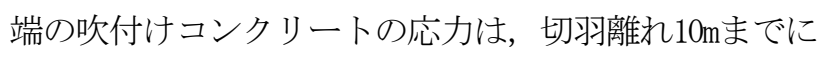
設計基準強度である $18 \mathrm{~N} / \mathrm{mm}^{2}$ に達しているのに対し，二 次支保工の打設後には応力が徐々に増加し, 最終的に19 $\mathrm{N} / \mathrm{mm}^{2}$ を超えている. また, 肩部や側壁の応力も二次支 保工の打設後に増加している. これは, 二次支保工によ り付与される支保内圧により一次支保工の耐力が復元し 地山の変位が一次と二次支保工に自然に分配され, 負担 されることによるものと考えられる.この解析結果は 図-13に示寸吹付けコンクリートの応力計測結果の傾向 をよく説明している.

\section{（4）支保工の高規格化}

前節と同様に物性值は地山-2を, 掘削パターンは 2 （二次支保工は1Dで施工）とし, 支保工の高規格化の検 討を実施した。解析に使用した高規格支保工の物性值は 表-2に示すとおり, 吹付けコンクリートはヤング率, 粘 着力, 降伏応力をそれぞれ通常の 2 倍とし, 鋼製支保工 はSS540として通常のSS400に対し降伏応力を約1.7倍と 想定した.

支保の仕様の組合せおよび総変位量の解析結果を表-4 に示す．想定した支保パターンは図-3と同様である.

一次支保工の吹付けコンクリートと鋼製支保工とを ともに高規格化した解析 2）は，一次と二次支保工が通 常の場合の解析 1) に対し総変位量で $22 \%$ の低減効果が

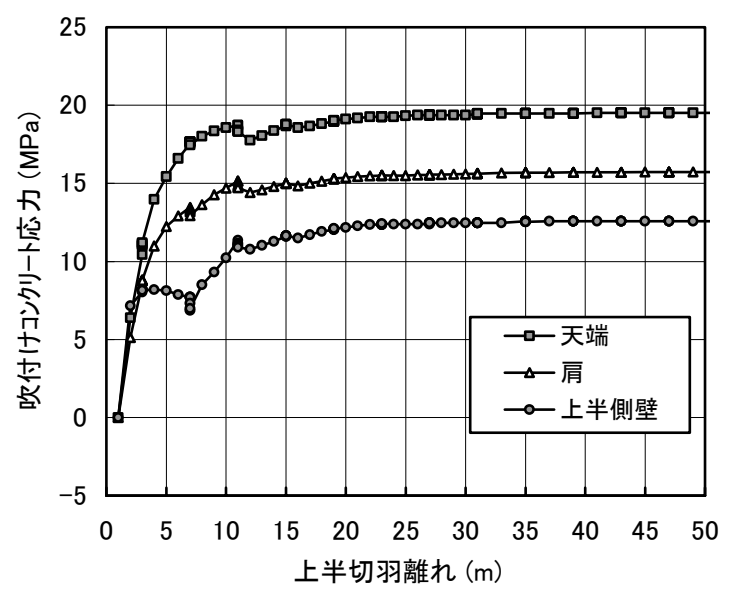

図-22 一次吹付けコンクリート上半部の応力

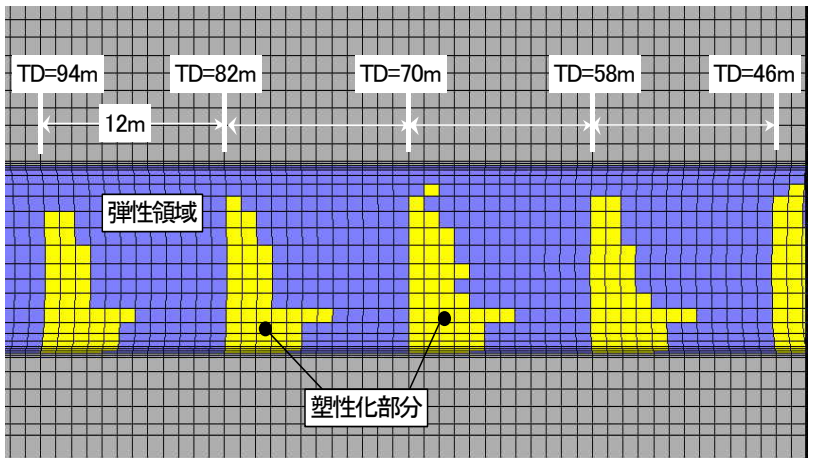

図-23 二次支保工の塑性化部分

表-4 支保の高規格化と総変位量 (mm)

\begin{tabular}{|c|c|c|c|c|c|c|}
\hline & \multirow{2}{*}{\multicolumn{2}{|c|}{ 解 析 }} & \multicolumn{4}{|c|}{ 支保工の仕様 } \\
\hline & & & \multicolumn{2}{|c|}{ 一次(剛性1/5) } & \multicolumn{2}{|l|}{ 二次 } \\
\hline & 掘削 & 掘削 & 吹付け & 鋼製 & 吹付け & 鋼製 \\
\hline & パターン 1 & パターン2 & コンクリート & 支保工 & コンクリート & 支保工 \\
\hline & $\langle 3.4 \mathrm{D}\rangle$ & $\langle 1 \mathrm{D}\rangle$ & $25 \mathrm{~cm}$ & $250 \mathrm{H}$ & $12.5 \mathrm{~cm}$ & $125 \mathrm{H}$ \\
\hline 地山-1 & 400 & 323 & 通常 & 通常 & 通常 & 通常 \\
\hline \multirow{4}{*}{ 地山-2 } & $=$ & 1)718(1.0) & 通常 & 通常 & 通常 & 通常 \\
\hline & - & 2) $561(0.78)$ & 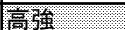 & 高跑， & 通常 & 通常 \\
\hline & - & 3) $573(0.80)$ & 暿 & 通常 & 通常 & 通常 \\
\hline & - & 4) $573(0.80)$ & 弦弦 & 通常 & 㗬弦. & 通常 \\
\hline
\end{tabular}

ある. 解析 2）に対し, 一次支保工の鋼製支保工のみを 通常に戻した解析 3）の変位量は 20\%であり, 鋼製支保 工の高規格化による変位の低減効果はあまり大きくない. さらに解析 4）において, 二次支保工の吹付けコンクリ 一トを高規格化しても大きな変位の低減効果は明瞭では ないという結果が得られた. これは二次支保工に発生す る変位量が一次支保工と比較して小さいことによるもの と考えられる.この結果, 一次吹付けコンクリートの高 強度化は地山条件がさらに悪くなった場合の有力な対策 となり得るものと考えられる.

なお，実施工において，解析 3）に対応するエトリン ガイト系混和材を使用した高強度吹付けコンクリートに よる約 $30 \mathrm{~m}$ 間の試験施工を実施した. 隣接する通常支保 適用区間と比較するとバラツキはあるものの, 総変位量 が平均で $39 \mathrm{~cm}$ から $28 \mathrm{~cm}$ に低减し (約 3 割程度) 一次支 
保工における吹付けコンクリートの高強度化の効果を確 認している.

\section{（5）二次支保工の塑性化}

地山の物性值は地山-2を, 支保工はi）通常を, 掘削 パターンは2（二次支保工は1Dで施工）を使用して解析 した二次支保工の吹付けコンクリートの塑性化した部分 を図-23に示寸. これは, 図-21の切羽離れ1Dの応力状態 がより顕著になったものであり，塑性化した部分は $12 \mathrm{~m}$ ピッチで施工すると想定した二次支保工の打継ぎ目から 後方 $5 \sim 6 \mathrm{~m}$ の範囲に発生し，インバート中央部側から側 面に広がっている. 同図は二次支保工が応力を分担して いる状況を表していると考えてよい. このような二次支 保工の変状が現れた場合には三次支保工を施工すること となるが，変状を防止するための対策としては，一次， 二次支保工の高規格化，二次支保工の一施工スパンを $12 \mathrm{~m}$ りも短くするなどの設計, 施工上の工夫が有効に なると思われる.

なお，アーチ部が弾性状態を保っていることから， 多重支保工法はトンネル施工中の安全確保という点でも 有利であると考えられる.

\section{6. 多重支保工の設計}

\section{（1）工法の考え方}

支保工の設置前に地山を変形させて地山の応力を開放 することにより，支保工に生じる応力が低減する効果は， 一般に「いなし効果 ${ }^{11} 」$ と呼ばれている. 北川ら $)^{2)}$ 指 摘しているように, 縫返し後の支保部材に発生寸る応力 が，縫返し前の支保工のそれより小さくなるのは，いな し効果によるものと考えてよい. ただし，制御すること なく変形を許した場合には, 重大な施工上の手戻りとな る「縫返し」を余儀なくされることも多い. トンネル掘 削の目的は必要な内空を安全に確保することであり, こ のために変位量を制御することは重要な課題である.

図-24はフェナー・パッハーの曲線12を用いて同曲線 のPminの発生位置よりも小さい変位領域で変位制御する ことを考える多重支保工法の概念を表現したものである. 掘削により変位があらかじめ設定した変形余裕量を超え 建築限界を支障する（a）の2）を避けるために(b)の1） を採用し，(b)の2）を避けるために(c)の1）を採用する ものである、いずれも2）は縫返しが必要となる．また， 二次と三次支保工は同図(b)の1），(c)の1）に示すよう に支保全体の反力が増加するように施工されなければな らない. (b)の3）では二次支保工は有効に機能していな い.

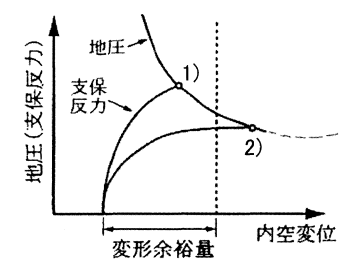

(a)一次支保 (通常)

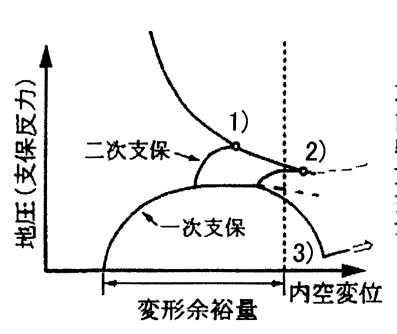

(b) 二重支保

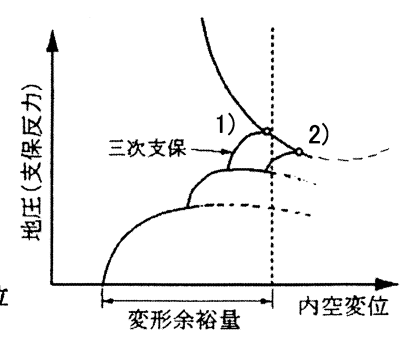

(c) 三重支保
図-24 多重支保工法の概念

本論文では多重支保工法をいなし効果と変位制御を組 从合わせた工法として取り扱う。一次支保工では変位を 管理しつつ，一次支保工の変状は容認して支保工が受け る地圧を軽減させる. 二次支保工は一次支保工に内圧を 与え，それぞれの支保工が十分に耐力を発揮するように 施工時期と仕様を決定し，地圧と支保工反力を釣り合わ せて変位が変形余裕量の内側に収まるように施工寸る合 理的な考え方である.

また，多重支保工法は施工および計測管理において特 別な段取りの必要がなく, 著しい膨圧下で仮に建築限界 に支障していても，二次支保工を施工寸ることにより切 羽を独立して進めることができる. このように多重支保 工法は施工上，簡単であり柔軟性に富んだ工法であると 思われる。

\section{（2）多重支保工の適用}

前述の検討，分析により多重支保工法の設計および支 保の手順を整理すると以下のとおりとなる.

1）従来の方法による膨圧性地山の掘削および計測結果 から，多重支保工法の採用を決定する。

2）総変位量を想定し，それに対する掘削時の変形余裕 量を設定する.

3）一次支保工の仕様を決定する.

4）二次支保工の仕様を決定する.

5）二次支保工の施工位置，あるいは施工時期を決定す る.

6）三次支保工の仕様，施工位置等を決定する.

7）掘削の状況，計測結果により 2）を見直す.

8）上記，3），4），5），6），7）を繰り返す.

変位量は多重支保工の施工による地山の応答であるこ とから，このような手順において，トンネルを安全に，

円滑に, 経済的に, 設定した変形余裕量の内側に変位を 


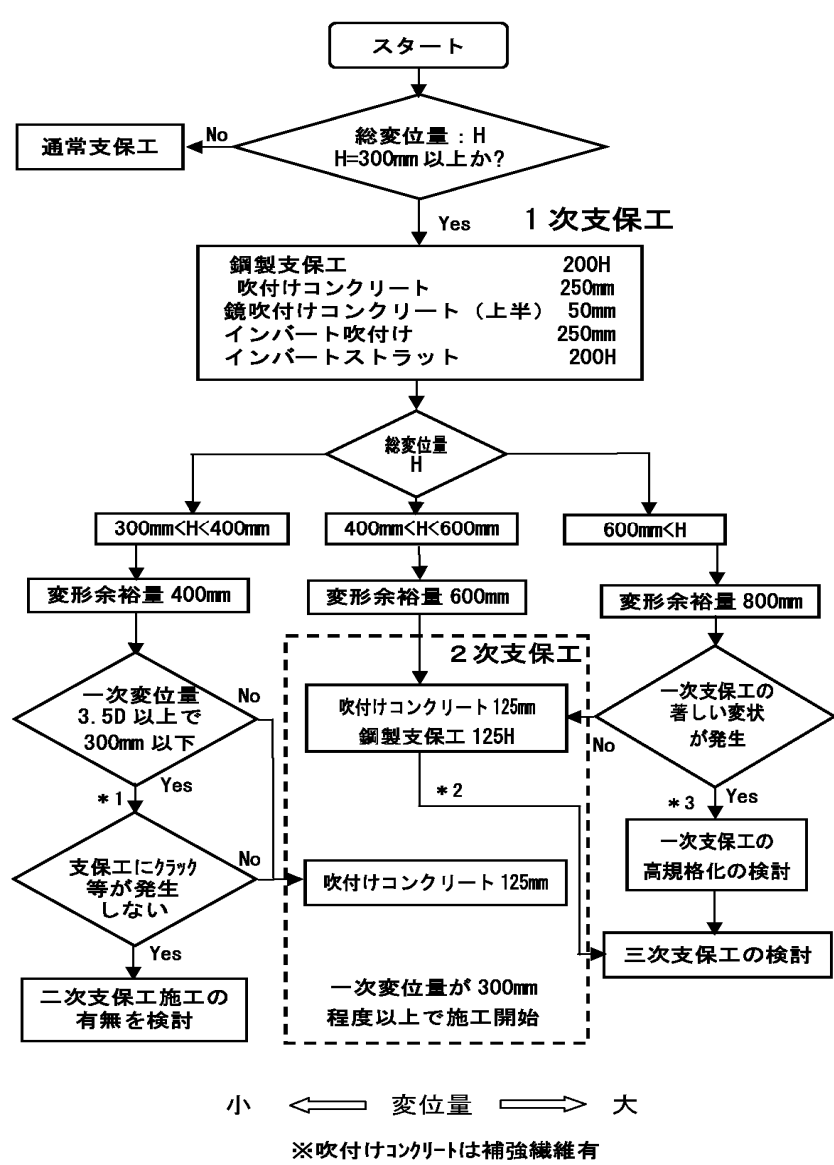

図-25飯山トンネルの多重支保工の手順
一連の切羽作業とは関係なく後方で二次支保工が施工で きるため施工性は良好である。 また，支保の損傷が軽微 で地山のクリープも小さい場合は, 周辺の地質状況も考 慮して，二次支保工の施工を省略することができる.

一次変位量が 400mm を超えると一次支保工の損傷が目 立つようになる，図中の*2は，このような状況におい て二次支保工の損傷を恐れず，その施工を速やかに実施 し，さらに変位発現に低減の効果が見られない場合には 三次支保工を積極的に施工寸ることにより，変位を抑制 するものである. 二次変位量は $50 \mathrm{~mm}$ 程度で管理する.

一次変位量が500mmを超えると一次支保工は著しい損 傷を受ける．二次支保工の施工を早めても対応できない 時は, 図中の*3のとおり一次支保工の高規格化が必要 となる．具体的には 4 章 (2)で述べた支保材の適用や鋼 製支保工のピッチの短縮等が有効であると思われる。ま た, 状況に応じ，二次支保工の高規格化，重量化を検討 する必要がある．さらに変位制御が難しい場合には三次 支保工を施工する.

これらの支保の手順を他のトンネルに適用する場合に は，そのトンネルの地山条件，支保構造と材料を良く検 討し適切な管理值を設定する必要がある.このためには, 大変形領域における支保工各部の応力と変位量の計測が 特に重要であると考えられる。

\section{7. 結論}

あるいは連動して，変位に与える影響について検討する 必要がある.

この考え方に基づき，飯山トンネルで使用した支保の 手順を図-25 に示寸。多重支保工法は大変形下で実施さ れる工法であり, その成否は使用する支保部材, 特に吹 付けコンクリートの変形性能が大きな影響を与える．飯 山トンネルでは，吹付けコンクリートに補強繊維を混入 して使用している点に留意する必要がある.

管理指標は基本的に変位量で実施することとした.

多重支保工法を採用寸るかどうかの判断は, 総変位量 として $300 \mathrm{~mm}$ 程度を目安とし, 初期変位速度 ${ }^{13)}$, ${ }^{14)}$ を使 用した一次回帰式により総変位量を想定することとした.

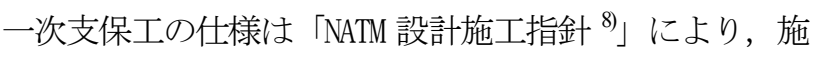
工性とのバランスを考慮した上で最大限, 重量化したも のである. 総変位量は経済性を考慮して 3 段階とし, そ れぞれに対応した変形余裕量を設定することとした.

二次支保工の施工時期を一次変位量が $300 \mathrm{~mm}$ 程度以上 としたのは一次支保工の吹付けコンクリートのクラック が変位量 $300 \mathrm{~mm}$ 程度から明瞭になることにより設定した ものであるが，状況によりこの管理值は増加してもよい．

同図中の* 1 は, 北川らの研究 ${ }^{2)}$ によるものであり, 切羽から 3.5D 以上離れても総変位量が $300 \mathrm{~mm}$ 程度であ れば概して有効であることを確認している。この方法は
飯山トンネルの膨圧性泥質岩地山における多重支保工 法について本研究で得られた主な知見を要約すると以下 のとおりである.

（1）多重支保工法は掘削に伴う変位を管理し，それぞれ の支保が耐力を十分に発揮するよう施工することに より変形余裕量内に変位を制御する施工法である.

（2）トンネルの変位を効果的に制御することができる適 当な一次変位量および二次変位量の管理值が存在す る. 飯山トンネルでは, 一次変位量は約 $300 \mathrm{~mm}$, 二 次変位量は約 $50 \mathrm{~mm}$ 目安とすることにより良好な 施工実績を得ることができた.

（3）支保工は応力伝達のためのスムーズな軸線を有して いることが基本である. このことから一次支保工に 過大な変位が予想される場合は，二次支保工を積極 的に, さらに必要により三次支保工を施工しなくて はならない。

(4) 一次支保工は, その吹付けコンクリートにクラック が発生しても相当の耐力が残存している. 二次支保 工は一次支保工に内圧を付与し支保工全体の耐力を 
増加させる役割をもつ.

（5）多重支保工法は，施工法として極めて柔軟性に富む 安全な工法であり合理的である.

(6) これらのことから「多重支保工の支保の手順」を提 案した.

今後の課題としては, 支保部材の変形性能の増加の方 策，コス卜低減を目的とした一次，二次支保工の支保仕 様のバランスと変位量の関係の整理が必要であると考え ている. 特に変位が増加しても耐力の減少が少ない吹付 けコンクリート材料の研究はトンネル全般においても重 要な技術課題である.

多重支保工法は，簡単に施工できることからより劣覀 な膨圧性泥質岩地山に，また，変位量の大きなさまざま な地山に変位制御を目的として広く適用されることを期 待したい.

謝辞 : 本論文の作成にあたり貴重な助言をいただいた早 稲田大学社会環境工学科小泉淳教授に深く感謝いたしま す.また, 膨大な各計測データを取りまとめ, 整理して いただいた関係各位にも心から感謝を申し上げる次第で 于.

\section{参考文献}

1) 光木香, 木幡芳文 : 北陸新幹線飯山トンネル地質調查最終報 告, トンネルと地下, Vol.31, No.7, pp.53-61, 2000.

2) 北川修三，梶原雄三，進士正人 : 施工時差を考慮した多重支 保工法の膨張性地山トンネルに対する適用, 土木学会論文 集, No.721/VI-57, pp.27-39, 2002.

3) 豊原正俊, 早坂治敏, 江戸川修一 : 鋼製支保工の高耐力化と 早期閉合で膨圧を克服一北陸新幹線朝日トンネル東工区, トンネルと地下, Vol.29, No.12, pp.7-17, 1998.

4) 秋田勝次, 佐藤一義 : 膨張性地山におけるトンネル掘削（北 越北線，鍋立山トンネル），土と基礎，Vol.41，No.3，pp.49-
52, 1993.

5) 柴田剛志，大沢光男 : 19年ぶりに導坑貫通の鉄道トンネルー 北越北線鍋立山トンネル，トンネルと地下，Vol.24，No.1， pp. 17-24, 1993.

6) 川本朓万, Ömer Aydan, 赤木知之 : 日本におけるスクィーズ イングトンネルの実態, 第24回岩盤力学に関するシンポジ ウム, 土木学会, pp.191-195, 1992.

7) トンネル標準示方書 [山岳工法編] - 同解説, 土木学会, p.135, 1996.

8) NATM設計施工指針，日本鉄道建設公団， 1996.

9) 剣持三平, 竹津英二, 青木智幸, 亀村勝美, 森田隆三郎 : 膨 張性地山トンネルの変形挙動に関する三次元解析, 第33回 岩盤力学に関するシンポジウム講演論文集, 審査付論文(2), pp. 9-16, 2004.

10) ITASCA Consulting Group: Fast Lagrangian Analysis of Continua in 3 Dimension Version 2.0， 2000.

11) たとえば, 高橋浩, 谷井敬春, 岩井勝彦, 桑原秀樹, 進士 正人, 中川浩二 : 膨張性地山における導坑の適用性に関す る実験的研究, 土木学会論文集, No.728 /VI-58, pp.27-39, 2003.

12) Pacher, F: Deformationsmessungen im Versuch-stollen als Mittel zur Erforschug des Gebirgsverhaltens und zur Bemessung des Ausbaues, Felsmechanik und Ingenieurgeologie, Suppl. I,1964.

13) 吉川恵也, 朝倉俊弘, 日吉直, 遠藤眞一 : NATM計測実績 の統計分析, 岩盤力学シンポジウム講演演文集, 1983年2 月.

14) 小島芳行, 朝倉俊弘, 吉川恵也 : NATMのための膨張性泥 岩の地山分類, 鉄道総研報告, Vol.3, No.5 pp. 49-55, 1989.

(2005.9.7 受付)

\title{
EFFECTS OF MULTIPLE-LAYER SUPPORTING METHOD IN SQUEEZING ARGILLACEOUS ROCKS
}

\author{
Sanpei KEMMOCHI, Eiji TAKETSU, Tomoyuki AOKI, Ryuzabro MORITA \\ and Hideki SHIRAHATA
}

The multiple-layer supporting method for a tunnel in squeezing argillaceous rocks is defined as the method to control the tunnel displacement within the displacement tolerance. Results of its application to Iiyama Tunnel are described. The respective functions of the first and second layer supports are examined based on the measured tunnel displacement and support stress behaviors. Three-dimensional numerical analysis on this tunneling method is performed to discuss the role of the second layer support applied at different distances from the face. The appropriate execution management conditions are proposed based on the execution experiences. Consequently, it is found to be a very flexible, secure and rational tunneling method. 